\title{
El campo en la ciudad. Representaciones y experiencias de los fematers en sus recorridos por Valencia (1878-1960)
}

\author{
The countryside in the city. Fematers' representations and experiences in \\ their travels around Valencia (1878-1960)
}

Jorge RAMÓN ROS

Universitat de València

\begin{abstract}
RESUMEN
Este artículo analiza, por un lado, cómo eran percibidas las relaciones entre l'Horta y la ciudad de Valencia por las autoridades municipales y la prensa a través de sus representaciones de los fematers (agricultores encargados de la recogida de desperdicios urbanos); y por otro, cómo la última generación de este oficio ha dado sentido a sus recorridos pasados entre el campo y la ciudad. De acuerdo a las fuentes interpretadas (documentación interna consistorial, literatura, prensa y entrevistas orales), son contrastados tres contextos distintos. En primer lugar, el de sus conflictos sociales con el incipiente gobierno blasquista a principios del siglo XX; en segundo lugar, una etapa de malestar agrario generalizado entre la I Guerra Mundial y el trienio bolchevique (1916-1921), y por último, en los albores del desarrollismo franquista en Valencia, etapa en la que desempeñaron su trabajo los fematers entrevistados.
\end{abstract}

PALABRAs CLAVE

Femater; agrourbano; Valencia; Horta; desperdicios.

\section{ABSTRACT}

This article, on the one hand, analyses how relations between the city of València and l'Horta, through its representation in the form of fematers (peasants in charge of urban waste collection), were perceived by the municipal authorities and the press. On the other, it examines how the latest generation of this profession has given meaning to its past journeys between the countryside and the city. Based on the sources employed (city council reports, literature, press and oral interviews), three different contexts are contrasted: firstly, their social conflicts with the incipient Blasquist government at the beginning of the $20^{\text {th }}$ century; secondly, the period of widespread agrarian unrest between the First World War and the Bolshevik triennium (19161921); and finally, at the dawn of Francoist developmentalism in València, the period in which the fematers interviewed were carrying out their work.

\section{KEYWORDS}

Femater; Agro-urban; Valencia; Horta; Garbage. 
Hace dos años, el Departamento de Asuntos Económicos y Sociales de la ONU publicó sus proyecciones sobre la evolución demográfica de la población mundial. Según este organismo, un 55\% vivía en 2018 en áreas urbanas y se preveía llegar al 68\% en $2050^{1}$. Un análisis similar aparecía en 2012 en una edición de El País con un título contundente: "El futuro pasa por las ciudades". A juicio de la redactora, si estos pronósticos se cumplían, "la vida pausada y bucólica con que los urbanitas asocian el campo y el mundo rural pasará a ser casi un recuerdo en color sepia” ${ }^{2}$. Sin embargo, la pandemia actual ha hecho patente la importancia vital de estos entornos en el territorio español, y no solo por el predominio de espacios abiertos y la hipotética paz asociada a su vaciado demográfico. A corto plazo, el golpe a la movilidad comercial y turística ha propiciado la extensión de debates sobre la sostenibilidad del modelo económico y, en concreto, de nuestro abastecimiento alimentario y de materias primas, y no solo sobre sus condiciones humanas o ambientales de producción y transporte. En España, la especialización agraria de las últimas décadas se ha basado en la premisa de que la importación, las infraestructuras y las redes de supermercados garantizarían fertilizantes y alimentos ilimitados a la carta, mientras se soterraba cualquier resquicio de carestía al precio de marginar y desprestigiar el potencial de los sectores agropecuarios de proximidad $^{3}$.

Este artículo no tiene como objetivo explorar este horizonte incierto, que supera los contornos de la investigación y el debate científico. Más bien, me interesa reflexionar, a partir de un caso concreto, sobre una idea subyacente en las fuentes iniciales. Campo y ciudad eran partes intrínsecas de una alteridad ontológica naturalizada, pero al mismo tiempo irreconocible en el presente, realidades disociadas a partir de mundos rurales y urbanos productores y producidos... ¿'solo por hipotéticos seres "urbanitas" y "rurales”? Una perspectiva ambiental que no diluya la agencia humana puede ser útil para complejizar las dicotomías presentes en estas lógicas ${ }^{4}$.

Por ello, he optado por estudiar la comprensión política y mediática de l’Horta y la urbe de València como entidades próximas pero no revueltas en tres contextos históricos distintos. En concreto, tomo como hilo conductor a un sujeto colectivo que con sus maneras de vivir el espacio ${ }^{5}$ podía reforzar, tensionar o redefinir los límites de estas entidades. Me refiero al femater, oficio complementario desempeñado hasta finales de los años 60 del siglo XX por una parte de los agricultores varones de la huerta del término municipal de València y pueblos limítrofes como Alboraia, Almàssera o Meliana. Consistía en la recogida de materia orgánica (estiércol y desechos

1. UNITED NATIONS, DEPARTMENT OF ECONOMIC AND SOCIAL AFFAIRS, POPULATION DIVISION, World Urbanization Prospects 2018: Highlights, Naciones Unidas, 2019, p. 1, https://population.un.org/wup/Publications/Files/WUP2018-Highlights.pdf (consultado el 15-12-2020).

2. Alicia GonZÁLEZ, “El futuro pasa por las ciudades”, El País, 15-4-2012.

3. Sobre estas cuestiones, una lectura recomendada es la de Carme MELO, “Crisis de Covid-19: soberanía alimentaria para evitar el desabastecimiento" The Conversation, 20-4-2020, https://theconversation.com/crisis-de-covid-19-soberania-alimentaria-para-evitar-el-desabastecimiento136266 (consultado el 15-9-2020).

4. William CRONON, uno de los primeros investigadores en advertir la historicidad de esta dicotomía, se preguntaba: "Why had I seen some human changes as 'natural' -the farm, the woodlot, the agricultural countryside- but not the other changes that had made 'nature' into 'city?” (Nature's Metropolis: Chicago and the Great West, Nueva York, W. W. Norton \& Company, 1991, p. 7).

5. Me he apropiado de la noción de “espacio vivido” de Henri LefeBVRE, La Producción del Espacio, ed. de Madrid, Capitán Swing, 2013, pp. 98-99. 
alimenticios) e inorgánica de las viviendas de la capital. Dichos grupos sociales asumían el vaciado de los desechos de los hogares de una calle determinada mediante acuerdos, costumbres o herencia familiar. Mientras que reaprovechaban los residuos biodegradables para fertilizar sus parcelas y dar de comer a los animales estabulados, el resto (papel, vidrio, trapos, chatarra...) solía ser vendido a otros lugareños, que transformaban estos elementos para darles nueva vida.

El femater, que aparecía a principios del siglo XX en multitud de crónicas de periodistas y escritores sobre el campo y la ciudad, protagonizaría enconados conflictos con los consistorios monárquicos de la Restauración y, a partir de 1901, con el hegemónico republicanismo blasquista ${ }^{6}$. Frente a éste protagonizaría una nueva etapa de conflictividad entre 1916 y 1921, que coincidiría parcialmente en la provincia de València con carestías, movimientos huelguísticos y asamblearios de jornaleros ${ }^{7}$, así como con el auge de sindicatos católicos agraristas ${ }^{8}$.

En las dos primeras partes del artículo, he analizado las narraciones y representaciones de los sujetos en conflicto principalmente a través de las crónicas locales de la prensa. En su mayoría, no eran enunciadas de manera impersonal ni tenían un autor individual claro, sino que se elaboraban en la redacción como capturas de la vida de la ciudad a través de otras fuentes. Frente al tono más distante del diario Las Provincias, las noticias de los conflictos callejeros en El Pueblo o El Mercantil Valenciano amalgaman los rumores, las experiencias personales o las declaraciones de las autoridades en relatos que producen una sensación de intensidad pese a su brevedad. En un par de párrafos, intentaban condensar las causas del enfrentamiento, los rasgos físicos y culturales de los personajes y la calle, las reacciones del vecindario o la moraleja de la historia narrada. Por ello, al enfrentarme a ellos, he de considerar que, de alguna forma, está intentando convencerme como lector de que ha habido una transgresión de comportamientos que debe ser respondida, en ocasiones de modo explícito, pero a menudo incierto.

La imposibilidad de interpretar su voz y de contrastar sus subjetividades ${ }^{9}$ con estos discursos públicos me incitó a aproximarme a un período posterior, de cuyos fematers había escuchado hablar. En este caso, los inicios del desarrollismo franquista coincidían con la experiencia de mi abuelo en esa labor. En consecuencia, y teniendo en cuenta una serie de condicionantes metodológicos (la utilización de dos tipos de fuentes con distinto público y naturaleza en dos contextos separados por brechas generacionales, una guerra civil y dos dictaduras) decidí abrir la investigación a la historia oral. En concreto, me resulta sugerente el giro interpretativo de ésta que, según Miren Llona, “propone desplazar el centro de interés de la reconstrucción de los hechos

6. Excepto breves lapsos y la dictadura de Primo de Rivera, su dominio político perduraría hasta la II República.

7. Joan DEL AlCÁzAR, Temps d'avalots al País Valencià (1914-1923), Valencia, Diputació de València, 1989, pp. 247-329.

8. Con independencia de su carácter antisocialista, Samuel GARRIDO ha sostenido que el impulso y la apuesta formativa del cooperativismo católico en mejoras técnicas de riego, cultivo y abonado; controlar el mercado de trabajo y facilitar el crédito fueron factores de atracción de pequeños y medianos propietarios y arrendatarios a estas organizaciones. (Treballar en comú: el cooperativisme agrari a Espanya (1900-1936), Valencia, Alfons el Magnànim, 1996, pp. 205-226).

9. Pese a organizarse parte de ellos como la Sociedad de Agricultores de la Vega, no se ha conservado en el presente documentación alguna de sus actividades cotidianas. 
a la búsqueda del sentido de los mismos y a la interpretación de la subjetividad" ${ }^{10}$. Al hacer esto, no estaba interesado en una labor de recuperación y dignificación del sujeto, entre otros aspectos porque los fematers de los años 1950-1960 no necesariamente poseían una larga tradición familiar o genealogía previa con la que identificarse. Más bien, me atraía cómo las personas entrevistadas dan sentido actual a su vínculo de antaño con el campo y la ciudad y modelan esa dicotomía, así como las diferencias o semejanzas que pueden apreciarse respecto a las fuentes literarias y periodísticas de principios de siglo. ¿Cómo se reconocían en aquel modo de vida? Además, esto podía permitirme explorar, a través de su recorrido vital, su evocación de los espacios urbanos de València y su interacción con ellos, al tiempo que recogían y aprovechaban el subproducto de las viviendas.

Respecto al método de la última parte, al principio opté por un formato intermedio entre la entrevista guiada y la narración libre de las personas entrevistadas, recurriendo o marginando mi cuestionario a medida que fluyesen sus hilos narrativos. El interés de mi abuelo le llevó a indicarme que no era el único agricultor ex-femater vivo en Alboraia. Con su mediación, conseguí entrevistarme con Enrique Panach López y Miguel Catalá Omedes, agricultores que siguen vinculados a l'Horta. Caso aparte es el de Manuel Belloch, dado que lo conocí más tarde mediante una conversación con su hija. Pese a que la intención inicial era realizar entrevistas individuales, la ilusión e implicación de mi abuelo en el proceso de búsqueda y logística me hizo descartar esa posibilidad a favor de conversaciones a tres bandas, a ser posible en sus casas de huerta. Era consciente de cómo podía condicionar la rememoración de vivencias íntimas, pero quizás me proporcionaba profundidad en el análisis de las complicidades tejidas entre antiguos compañeros o la negociación en directo de las discordancias entre sus pasados vividos. Pese a los errores gramaticales y léxicos de las personas entrevistadas, he optado por transcribirlos en valenciano normativo junto a retazos de su lenguaje corporal y sus énfasis o vacilaciones (marcados entre corchetes). Lo he hecho así, primero, para no condicionar en exceso la cadencia y la organización interna de sus relatos, y segundo, para entender mejor cómo valoraban a la luz del presente sus vidas y encuentros a caballo entre el campo y la ciudad.

A diferencia de los argumentarios blasquistas, que conceptuaban estas comunidades como reductos privilegiados de un pasado pre-higiénico, València no era la única ciudad en la que los trabajadores del campo ponían en valor los residuos de la actividad humana y animal en los hogares a finales del siglo XIX. Labradores de otras urbes con regadíos aledaños, como Murcia ${ }^{11}$ o Granada, también transitaban las calles en búsqueda de los desperdicios vecinales. Asimismo, la procedencia periurbana del femater y sus labores de reaprovechamiento y reventa guardan semejanzas con la del trapero madrileño, si bien la labor de éste no poseía una vinculación estrictamente agraria. En los años 30 del siglo XX, su figura sería objeto de debates municipales al tiempo que las autoridades buscaban alternativas para afrontar de manera sistemática el

10. Miren LlONA, "Historia Oral: la exploración de las identidades a través de la historia de vida”, en ídem (ed.), Entreverse: Teoría y metodología prácticas de las fuentes orales, Bilbao, Universidad del País Vasco, 2012, p. 46.

11. María Teresa PÉREz PiCAzo, Oligarquía urbana y campesinado en Murcia 1875-1902, Murcia, Academia Alfonso X El Sabio, 1986, pp. 108-110. 
volumen en alza de "lo residual”"12. De este modo, y más allá de casos particulares, sería interesante estudiar la vigencia y valoración desigual de estas prácticas en relación con los problemas sociales y ambientales derivados de la acumulación de desperdicios en ciudades españolas con un creciente número de industrias y habitantes. En urbes como Bilbao, el abastecimiento de agua potable dependía hasta entonces de los mismos acuíferos a los que iban a parar los vertidos, por lo que la recogida de basuras debía ser acompañada de soluciones pendientes en materia de alcantarillado y fontanería ${ }^{13}$. Al otro lado del Atlántico, la municipalización y estandarización del servicio de limpieza y la introducción de sistemas mecánicos ya había sido justificada por algunas elites ingenieriles a partir del cambio de siglo en base a los nuevos ritmos que marcaba el creciente tráfico motorizado ${ }^{14}$. A falta de esta tecnología y de reorganización laboral, las tareas de basureros, traperos o fematers podían cobrar una dimensión higiénica y circulatoria esencial en las ciudades que rebasaba el beneficio individual de las familias que las ejercían.

Además, la reutilización de los residuos también gozaba de cierto atractivo en determinados contextos de intensificación agraria en regiones periurbanas de Europa Occidental o Estados Unidos. Joel A. Tarr, uno de los pioneros de la historia ambiental, hacía referencia al trabajo de "the night-soil men", que hasta 1912 vaciaban los pozos ciegos en urbes sin alcantarillado como Baltimore y vendían los desperdicios vendidos a contratistas que los transportaban en barcaza hasta los campos y granjas adyacentes a la ciudad $^{15}$. En Francia, Sabine Barles ha analizado cómo el tráfico del lodo callejero parisino impulsaría entre 1880 y 1910 la productividad del trigo, las plantas forrajeras y otros cultivos en las tierras situadas en un radio de 50 kilómetros desde la capital. Tras los brotes de cólera de 1884-1885, el cieno marsellés sería comercializado en ferrocarril por empresas con apoyo estatal y adquirido por agricultores de la plaine de la $\mathrm{Crau}^{16}$. Mientras tanto, la fertilización con estiércol de la cabaña ganadera había sido, según Manuel González de Molina, la base de una creciente productividad de la agricultura española hasta los años setenta del siglo $\mathrm{XIX}^{17}$. No obstante, dada la diversidad territorial y social de esta actividad, la perspectiva que ofrece este autor de la integración agropecuaria, marcada por sus análisis sobre la vega de Granada, debería ser revisada para l'Horta de València. En ella no escaseaban las familias arrendatarias con cerdos, vacas, cabras y gallinas estabuladas en sus alquerías. Así pues, el estiércol no

12. Luis Enrique OTERO CARVAJAL y Nuria RODRÍGUEz MARTíN, "Infraestructuras urbanas y modernidad. Madrid, nuevas necesidades y servicios de una metrópoli moderna, 1900-1936”, Historia Contemporánea, 59 (2019), pp. 28-33 (https://doi.org/10.1387/hc.18522).

13. Pedro A. Novo ha analizado la problemática de lo residual en Bilbao en un contexto de creciente densidad demográfica, industrialización y contaminación acuífera, si bien era una ciudad sometida a procesos más intensos y vinculados al combustible fósil ("Sanear la ciudad. La gestión de los residuos urbanos en Bilbao (1875-1930)” en Manuel MONTERo (ed.) La ciudad y el progreso: la construcción de la modernidad urbana, Granada, Comares, 2019, pp. 81-103).

14. Martin V. Melosi, Garbage in the Cities: Refuse, Reform and the Environment, Pittsburgh, University of Pittsburgh Press, 2004, pp. 111-115 (https://doi.org/10.2307/j.ctt5vkf00).

15. Joel A. TARR, The Search for The Ultimate Sink: Urban Pollution in Historical Perspective, Akron, University of Akron Press, 1996, p. 348.

16. Sabine BARLES, L'invention des déchets urbans. France: 1790-1970, Seyssel, Champ Vallon, 2005, pp. 177-182.

17. Manuel GonZÁLEZ DE MolinA, “Crecimiento agrario y sostenibilidad de la agricultura española de los siglos XVIII y XIX”, en Ramón GARRABOU (ed.) Sombras del progreso: las huellas de la historia agraria, Barcelona, Crítica, 2010, pp. 338-346. 
era el único material por el que labradoras y labradores ocupaban las calles de la ciudad. El creciente consumo en ella y los pueblos próximos de bebidas lácteas había propiciado una red de lecherías y vaquerías, desarrollada sobre todo en los bordes de las carreteras que conectaban ambos entornos ${ }^{18}$.

\title{
Lazos agrourbanos: potencial económico y fermento de conflictividad (1878-1903)
}

A fines del Antiguo Régimen, el marqués de la Torre del Carrús, concejal municipal cercano a la ilustrada Sociedad Económica de Amigos del País, ligaba intrínsecamente la prosperidad agrícola a la recogida de los desechos de la València amurallada. Ese vínculo a la vez, mejoraba la producción y calidad de las frutas y verduras expendidas a sus residentes:

una materia, al parecer tan despreciable, y sórdida, como es el polvo, y estiércol de estas calles; pero tan útil, y necesario a nuestros campos, que de él y en su elogio podemos en conclusión, y en pocas palabras: él nos sustenta ${ }^{19}$.

Pero, ¿qué ocurría si esta relación era paralizada? Desde mediados del siglo $\mathrm{XIX}$, los fematers habían protagonizado diversas huelgas junto a las vendedoras de verduras y hortalizas que habían saboteado el tráfico y el abastecimiento de alimentos de la ciudad. En 1882, El Mercantil Valenciano, periódico liberal-republicano con gran tirada en la ciudad, valoraba sus comportamientos en una de ellas en los siguientes términos:

\begin{abstract}
Ya estarán satisfechos los torpes consejeros de los labradores; se quedarán estos sin sus puestos en los mercados, perdiendo las ganancias que legítimamente les producía la venta al detalle de la cosecha, y cuando la miseria y el hambre llamen a las puertas de las humildes barracas: ¿dónde estarán esos señores que les alientan ahora? ¿Dónde estarán ahora esos caballeros que escriben los pasquines, esos que en fin, directa o indirectamente, mantienen la excitación de la huerta? ${ }^{20}$
\end{abstract}

De esta columna parece deducirse que son seres inocentes manejados por agentes externos, asociados, en otras crónicas, al carlismo arraigado en l'Horta. Para entender esta identificación territorial y social, es importante considerar que en los ayuntamientos de pueblos levantados como Almàssera o Alboraia gobernaban notables conservadores y católicos que, ante el auge republicano, organizarían alianzas como la Liga Católica entre 1905 y 1907²1. La reintroducción del sufragio universal no alteraría

18. Salvador Calatayud y Francisco J. MedinA-Albaladejo, "Leche sin prados: los factores ambientales e institucionales en el consumo lácteo (Valencia, 1870-1936)”, Ayer, 105, 1 (2017) pp. 170 y 172.

19. MARquÉS DE LA TORRE DE CARRÚS, Discurso sobre lo útil y aun necesario que se cree ser a los campos de la huerta de esta Ciudad el estiércol y el polvo que se saca de sus calles, y perjudicial a la salud pública que permanezca en ellas. Valencia, Oficina de D. Benito Monfort, 1788, p. 53.

20. El Mercantil Valenciano, 23-7-1882.

21. En las elecciones generales de 1901, el carlismo alborayense “aportaba 654 de los 5.546 votos obtenidos [...] en la gran circunscripción electoral que incluía la capital provincial” (Javier ESTEVE MARTí, "La política antiliberal en España bajo el signo del nacionalismo: el padre Corbató y Polo y Peyrolón”, tesis doctoral, Universitat de València, 2017, p. 214. 
esta composición institucional, mantenida en muchas de estas localidades hasta la II República, no sin manipulaciones ${ }^{22}$ y conflictividad social.

En un plano literario, Blasco Ibañez representaba al femater en Nelet, labrador adolescente, como "un explorador de misterioso territorio" cuya experiencia de la ciudad era "la ruidosa batahola del Mercado y aquellos municipales de torvo ceño y cerdosos bigotes, terror de la gente menuda" ${ }^{23}$. Tanto en las narraciones literarias como en la prensa, la plaza del Mercado destacaba como lugar de intercambio económico, pero también de encuentro y desencuentro social. Sus tenderetes al aire libre, atravesados por tranvías en la última década del siglo XIX, serían objeto de debates mediáticos sobre su decoro y los proyectos arquitectónicos que no cristalizarían hasta 1910. A ello se sumaba un pasado y presente marcado por sus apropiaciones "en nombre del pueblo" como enclave de confrontación contra el ejército, frente a la disolución de las milicias nacionales en 1869, o contra la intervención militar dictaminada durante el alzamiento por la recaudación de los consumos en $1887^{24}$.

¿Cómo interpelaba este relato a aquellos que abrían su domicilio para que recogiesen diariamente sus residuos? La proyección del novelista evoca a la antropología que, según Jesús Izquierdo, el liberalismo español finisecular había modelado sobre el campesinado, presentándolo como seres de otro mundo, dominados e inconscientes que, en última instancia, no eran dueños de su vida ${ }^{25}$. Pero en su lugar, es probable que, dada la cotidianeidad de las labores del femater, el desconocimiento mutuo y la desconfianza que representaba entre los vecindarios de la ciudad y éste no tuviese mucho fundamento.

Desde una perspectiva atravesada por los estudios de género y la historia agraria, Mónica Burguera defendía que las huelgas de 1878 y 1882 habían incidido en las percepciones de las elites políticas, la prensa y los círculos literarios de València sobre el mundo agrícola que interactuaba con la urbe. Si bien gozaban de resonancia las imágenes bucólicas de las familias rurales de una interdependencia armónica con la urbe, las crónicas periodísticas sobre la huelga insistían en la violencia, irracionalidad y alienación de las vendedoras y labradores en el espacio urbano ${ }^{26}$. Ahora bien, esta perspectiva se torna más compleja al ser contrastada con discursos que remitían a

22. En las primeras crónicas de El Pueblo sobre Alboraia, la familia Rubio aparecía como núcleo del caciquismo católico y ostentó la alcaldía durante largos períodos. Treinta años después, uno de ellos sería sospechoso de amañar las elecciones, hasta el punto de que el Gobernador Civil ordenó la repetición de comicios en éste y otros 128 municipios de la provincia. El nuevo resultado propiciaría la elección de un alcalde republicano (María José SIGALAT VAYÁ, La II República en Alboraia: 1931-1936, Alboraia, Ajuntament d'Alboraia, 1995, pp. 105-110).

23. Vicente Blasco IBAÑEZ, "El Femater” en Cuentos Valencianos, Valencia, Francisco Sempere, 1910, p. 167.

24. Estas cuestiones son examinadas en mi tesis doctoral "València en la Restauración: reformas y percepciones sociales del espacio urbano (1875-1910)”, defendida en la Universitat de València en marzo de 2021.

25. Jesús IZQUIERDO, "El ciudadano demediado: campesinos, ciudadanía y alteridad en la España contemporánea” en Manuel PÉREz LEDESMA (ed.), De súbditos a ciudadanos. Una historia de la ciudadanía en España, Madrid, Centro de Estudios Políticos y Constitucionales, 2007, p. 631.

26. Mónica BuRgUerA, “La política de los paisajes campesinos en la ciudad: mujeres, niños y resistencia familiar en la Valencia de la segunda mitad del siglo XIX” en ídem y Christopher SCHMIDT-NOVARA (eds.), Historias de España Contemporánea: cambio social y giro cultural, Valencia, PUV, 2008, pp. 81114. 
marcos de convivencia. Por ejemplo, en 1878 El Mercantil Valenciano había jaleado la preocupación lectora ante una inminente parálisis de su actividad que repercutía en los negocios:

\begin{abstract}
no es solamente [...] lo que compran las labradoras, sino que éstas se surten de muchas cosas en los comercios de especiería, y cuanto necesitan para vestir a todas sus familias, en los comercios de tejidos, dejándose muchas veces en estos últimos algunos miles de reales.

Sufre [el comercio] porque muchas familias de la capital, temerosas de que suceda algún motín, se retraen de salir a compras.

Sufre porque los habitantes de los pueblos de la provincia no vienen, porque ha cundido la voz de que aquí nos estamos matando ${ }^{27}$.
\end{abstract}

Dos décadas después, y en un contexto de ruptura del turno dinástico en la ciudad del Turia, la voluntad de fematers y vendedoras de ir a la huelga volvía a preocupar a los políticos y la prensa. En esta ocasión, las protestas giraban en torno a una organización agrícola con una red asentada en la huerta: la Sociedad de Agricultores de la Vega (SAV). Según el registro de Asociaciones, fue fundada en 1900 con 300 personas inscritas, y dos años después contaba con 2.317 asociados $^{28}$. Aunque resulta complicado por el momento inferir aspectos de su estructura, composición social o arraigo en las redes políticas de los pueblos de la huerta, semejante evolución la convertiría entonces en la entidad con mayor volumen y crecimiento de miembros en el hinterland de València.

En el pleno de debate sobre el impuesto a los carros huertanos, el escribano municipal retrataba la sala de juntas como un espacio de deliberación racional asediado por el público:

\begin{abstract}
la Alcaldía aceptó a su vez la indicación del Sr. Taroncher, y designó a este y a los Sres Montesinos, Rubio y Simó para que convencieran al público de la necesidad de guardar orden y eligieron a seis individuos, que eran los más que podían caber en el consistorio. Suspendióse la sesión por breves momentos con objeto de que dichos señores pudieran cumplir su encargo y regresaron estos después sin que sus exhortaciones hubieran conseguido moderar la actitud del público, que seguía pugnando por penetrar en el salón y en actitud tumultuaria ${ }^{29}$.
\end{abstract}

Días antes, El Pueblo, al principio partidario de la no fiscalización de los carruajes agrícolas, había matizado el tipo de labrador al que querían defender. En concreto, establecía distinciones entre "aquellos que hacen política" y "la sencillez de los labradores”. Cabe interpretar de sus declaraciones que los intereses y las acciones protagonizadas por los sujetos agrícolas estaban y debían estar al margen de la política municipal.

Esto se sobreentiende que será mientras los huertanos se limiten a proceder como tales, defendiendo sus intereses con independencia y sin dar a su protesta un alcance político en favor de determinado partido.

Y decimos esto porque se nos asegura que ciertos elementos políticos, especialmente los carlistas, pretenden explotar este conflicto para sus fines electorales en Alboraya y Almácera [...] las canallescas mentiras que hacen circular contra los concejales de la

\title{
27. El Mercantil Valenciano, 13-3-1878.
}

28. ARXIU DEL REGNE DE VALÈNCIA, fondo Administración Central Delegada, libro del Registro de Asociaciones n ${ }^{\circ} 1$ (1887-1911).

29. ARXIU HISTÒRIC MUNICIPAL DE VALÈNCIA (AHMV) actas del pleno consistorial, 6-5-1901. 
Fusión, nos hacen ver que se pretende explotar esta agitación contra los republicanos, abusando de la sencillez de los labradores ${ }^{30}$.

Este argumento sería reiterado por la prensa blasquista durante las movilizaciones de vendedoras y fematers entre 1901 y 1903. En paralelo, iba asociado a una imagen mediática de ambos como entes externos privilegiados que se adentraban y aprovechaban de la ciudad y el consistorio para realizar sus labores cotidianas (abastecimiento de alimentos y recolección de desperdicios). Si éstas no se efectuaban, su presencia e interacción con la ciudad cobraba tintes amenazadores para el gobierno de la misma, asociado a la circulación regulada de personas y mercancías ${ }^{31}$. El Pueblo, cuyas pretensiones de representatividad popular habían sido reforzadas por la mayoría relativa del republicanismo blasquista desde 1901, denunciaba la supuesta excepcionalidad del femater:

Se sigue respetando la costumbre de los fematers, que se llevan el mejor estiércol, ensucian las calles, entran y salen a la hora que les da la gana y no guardan ninguna de las reglas de aseo e higiene más elementales.

En ninguna otra población de España se conoce eso de los fematers. El producto del estiércol de las habitaciones sería suficiente para costear un servicio perfecto de limpieza pública en Valencia, como se hace en todas partes ${ }^{32}$.

En estas protestas, en las que colaboró asiduamente la SAV, las crónicas del diario de Blasco u otros como El Mercantil o El Correo destacarían desde distintos ángulos la vertiente irracional, violenta y expansiva de las movilizaciones. Raro era el día en el que no denunciaban las talas de campos, los cortes de caminos o, en el centro de la antigua ciudad intramuros, la paralización de la venta en el Mercado, ocupado por otros usos del espacio público. Por ejemplo, El Correo iniciaría sus crónicas con el provocador título de "Valencia invadida por los labradores". Para el diario liberaldemócrata, esta incursión suponía convivir con una diversidad de manifestaciones públicas alejadas de la distancia corporal y el aislamiento sensorial analizados como señas de respetabilidad urbana en otros territorios ${ }^{33}$. Así pues, el disparo callejero de cohetes, supuestamente dirigido por "algunos chiquillos y huertanos amigos de estas diversiones” era asociado a la expulsión de transeúntes que nada tenían que ver con los incidentes. El propio destrozo de las frutas y verduras contra el suelo de la plaza hacía imposible el tránsito ${ }^{34}$.

30. "Los huertanos”, El Pueblo, 5-5-1901.

31. Un ejemplo del vínculo entre circulación y gobierno en el desarrollo de metrópolis en Richard DenNIS, Cities in Modernity: Representations and Productions of Metropolitan Space, 1840-1930, Cambridge, Cambridge University Press, 2008, pp. 39-40.

32. “Los huertanos”, El Pueblo, 9-12-1902.

33. Simon GunN, The public culture of the Victorian middle class: Ritual and authority in the English industrial city 1840-1914, Manchester, Manchester University Press, 2007, pp. 76-77, y Chris OTTER, “Making Liberalism Durable: Vision and Civility in the Late Victorian City”, Social History, vol. 27, n. 2 (2002) p. 2.

34. “Valencia invadida por los labradores”, El Correo, 6-4-1901. 
Figura 1: Extensión de la conflictividad agrourbana en l'Horta Nord calculada a través de la procedencia de las personas detenidas en mayo de 1901 (círculos) y de las sociedades firmantes de los manifiestos de huelga en junio de ese año (cuadrados).

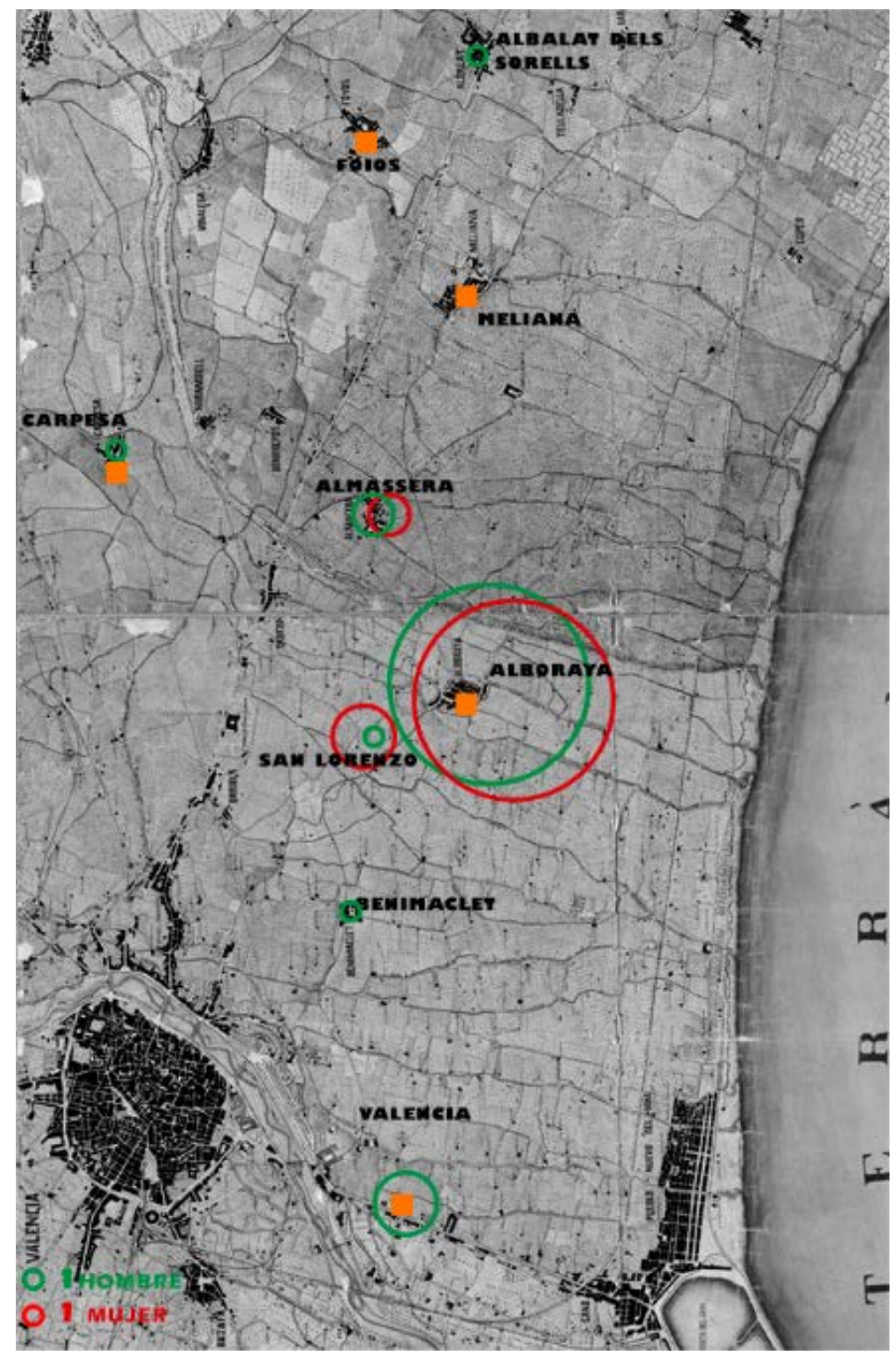

F: El Pueblo, 5 de mayo de 1901 y La Voz de Valencia, 29 de junio de 1902. Plano original: Plano de Valencia y sus alrededores, Cuerpo de Estado Mayor del Ejército, 1883.

La importancia de la circulación comercial y la movilidad personal para los blasquistas afloraba en "La Revolución de Valencia”, proyecto "inclusivo-expansivo" de ciudad esbozado en El Pueblo tras su victoria en las elecciones municipales de 1901. Rememorado posteriormente como mito fundacional de la política blasquista de reforma urbana, aglutinaba desde la construcción de escuelas, avenidas y zonas verdes hasta una nueva red de alcantarillado. No obstante, ¿cuál era el presente que Blasco había dibujado frente a este futuro? Calles convertidas en vertederos, caminos angostos de huerta, un mercado "a estilo moruno" donde "los artículos comestibles se ofrecen sobre el barro de los adoquines". Concluía que, si su plan fracasaba, "tendámonos de nuevo en el estercolero, resignados a esta vida de bestias bajo el cielo más hermoso y el suelo más infecto del mundo"35. Entre líneas, hablaba de una ciudad lastrada por una 
interdependencia agrourbana, en el marco de una oposición mitificada entre "I’horta esclavitzada i clerical i la ciutat lliure i republicana" ${ }^{36}$.

Tras las huelgas, las autoridades municipales tomaron medidas para zanjar el conflicto agrario que, de acuerdo a Ramiro Reig, supusieron una victoria del Ayuntamiento sobre los fematers. Después de encargarse del servicio de limpieza entre 1904 y 1906, conseguiría zafarse de este asunto en 1907, dejándolo en manos de un licitador privado a cambio de 108.490 pesetas $^{37}$. No obstante, no queda claro si el nuevo arrendador englobaba las tareas de limpieza callejera, que en los años 80 del siglo XIX aparecían ligadas en las denuncias municipales a encargados particulares ${ }^{38}$, así como la recogida de residuos de los hogares. Por ello, resulta una incógnita las consecuencias que provocaría este contrato en el oficio de los fematers. A falta de un acceso legislado a la materia orgánica, sus herramientas de presión y trabajo parecían reducirse.

\section{De divorcios, complicidades y coacciones mutuas (1916-1921)}

En un contexto de movilizaciones sociales y laborales generalizadas en la provincia de València, las polémicas mediáticas y políticas sobre el poder de los agricultores de l'Horta proliferaron a partir de 1916. Pero en esta ocasión se insertaban en una preocupación más amplia de las autoridades por la conflictividad que podía despertar la distribución y fiscalización de la producción agraria. Tras el estallido de la I Guerra Mundial, las ondulaciones comerciales, el alza de los precios alimenticios y, sobre todo, la amenaza del hambre habían catalizado protestas multitudinarias en gran número de pueblos de La Rioja antes del llamado trienio bolchevique ${ }^{39}$. Por otro lado, no puede soslayarse la influencia de conflictos en torno a la apropiación de recursos comunales y en general, la vulneración de supuestas costumbres y acuerdos tácitos en el aprovechamiento de la tierra, como fue el caso de las Ribera navarra a principios del siglo $\mathrm{XX}^{40}$.

En los pueblos circundantes a València, la inestabilidad comercial provocada por el inicio de la guerra había frustrado las expectativas generadas por las exportaciones de arroz, naranja, cebollas o patatas. Según Joan del Alcázar, el malestar causado por esta coyuntura podía unir a grupos agrícolas de diferente condición socioeconómica: "Què havien de fer els jornalers i els petits propietaris si es paralitzava la collita perquè els fruits no tenien eixida? És clar que el que els pertocava era fer costat als propietaris $i$ als comerciants" ${ }^{41}$. Ahora bien, quedaría pendiente abordar cómo sentirían esta situación aquellas familias que, sin necesidad de intermediarios y mercados lejanos, vendían directamente en la ciudad. Tampoco deben obviarse diversas confluencias entre ellas y los obradores de la capital. A principios de 1916, una huelga de horneros causada

36. Ramiro REIG, “La invenció de València”, Afers, 31 (1998), p. 575.

37. Ramiro ReIG, Blasquistas y clericales: la lucha por la ciudad de Valencia en 1900, Valencia, Institució Alfons el Magnànim, 1986, pp. 350-351.

38. AHMV, Policía Urbana, caja 139, exp. 51, 1882.

39. Carlos GIL ANDRÉS, Echarse a la calle: amotinados, huelguistas y revolucionarios (La Rioja, 18901936), Zaragoza, Prensas Universitarias de Zaragoza, 2000, pp. 123-127.

40. José Miguel Gastón, ;Vivan los comunes! Movimiento comunero y sucesos corraliceros en Navarra (1896-1930), Tafalla, Txalaparta, 2011, pp. 187-255.

41. Temps d'avalots al País Valencià, p. 126.

Rubrica Contemporanea, vol. X, n. 19, 2021. 
por las exigencias de los harineros se convirtió en general y recibió el apoyo de las vendedoras agrícolas, cesando su actividad en los mercados. No obstante, estos lazos entre trabajo/producción agrícola e industrial eran intermitentes. Aunque una de las exigencias socialmente extendidas era una agroexportación fluida que beneficiase a toda la cadena alimentaria, esta situación proporcionaba una cierta capacidad de presión, en caso de desabastecimiento, a las familias labradoras arrendatarias o propietarias. A finales de 1916 y principios de 1917, la negativa del Gobierno a la exportación de remanentes de patatas aunó en la capital a propietarios, arrendatarios y jornaleros en huelga, mientras que el alza creciente de los precios de alimentos repercutía sobre todo en aquellos que no podían cultivarlos ${ }^{42}$. Cualquier paro de las vendedoras y los fematers a la ciudad en solidaridad con estas protestas era declarada como una "guerra al vecindario" por El Pueblo: “como al parecer no encuentran recursos con que combatir al Gobierno [...], nos combaten a todos nosotros, dificultando el aprovisionamiento de este mercado y amontonando las basuras en nuestros hogares" ${ }^{43}$.

Similares amenazas se materializarían en 1919 en una nueva huelga huertana. La confección de los presupuestos municipales de València había sido difícil, al arrastrar un déficit de más de un millón de pesetas con el que se pretendía justificar previsibles aumentos de impuestos en inquilinato, peajes, pesaje público, etc. ${ }^{44}$. En este contexto, es comprensible que las reivindicaciones de fematers al consistorio incidiesen en viejas cuestiones, como la fiscalización de sus carros y cargas o la extracción de la arena del Turia, preciada por su permeabilidad para mejorar la calidad del suelo. Protestas por la fiscalización económica, pero también por las trabas al acceso diario a la ciudad y su trabajo, en consonancia con la pluralidad de motivaciones para movilizarse en la politización campesina contemporánea ${ }^{45}$.

Además, ahora surgían otras exigencias, vinculadas a la vivienda: "Que se elimine del pago del arbitrio sobre Inquilinato a todos los labradores que habiten casa de alquiler inferior a 25 pesetas mensuales, aunque sean propietarios de la casa”46. Este gravamen, vinculado a la extinción de los consumos en 1911, era defendido por una parte de las elites conservadoras y algunos republicanos del Congreso. Sin embargo, a partir del final de la guerra, el malestar sobre las condiciones del alquiler había precipitado en otras ciudades la creación de movimientos vecinales e incluso la sindicación de inquilinos ${ }^{47}$. La mayoría de familias labriegas de la zona eran arrendatarias o dependían del jornal, por lo que previsiblemente estarían interesadas en la supresión de este impuesto. Empero, las menciones a los propietarios en sus proclamas generan más dudas. La diversidad dentro del sujeto huertano era admitida

42. Ibídem, pp. 261-263.

43. "Huelga de huertanos. Porque no sale la patata, no entran los 'fematers'”, El Pueblo: diario republicano, 23-5-1917, p. 2.

44. ARCHIVO DE LA REAL SOCIEDAD ECONÓMICA DE AMIGOS DEL PAÍS DE VALENCIA, caja 307, legajo XXI, signatura 04.

45. David Soto y Antonio HerrerA, "El conflicto agrario en la historia contemporánea de España. Nuevas perspectivas de análisis”, Vínculos de Historia, 3 (2014) p. 78.

46. “Lo que piden los huertanos”, Diario de Valencia, 15-1-1919.

47. Miguel ARtola Blanco, "La transformación del mercado de alquiler de fincas urbanas en España (1920-1960) Geo Crítica. Cuadernos de Geografía Humana, 15-8-2012, http://www.ub.edu/geocrit/b3w988.htm. 
incluso por el Ayuntamiento, que eximiría de pago a las familias arrendatarias de menos de diez anegadas ${ }^{48}$.

Pese a estas novedades en las motivaciones de la movilización, los discursos mediáticos giraban una vez más sobre el abastecimiento y la limpieza. El fantasma de la carestía, la violencia y los privilegios agrícolas sería utilizado como arma arrojadiza por El Pueblo, que acusaba a las sociedades en huelga de boicotear las negociaciones con la alcaldía e "imponer a la ciudad” sus condiciones:

El que los huertanos, después de habérseles demostrado la imposibilidad de eximirles del pago de arbitrios que pagan los demás vecinos, busquen por la violencia de la huelga el triunfo de sus exigencias, evidencia que pretenden imponer a la ciudad, que para evitar la carestía de verduras se conceda al huertano una situación de privilegio ${ }^{49}$.

Mientras tanto, Las Provincias relativizaba las alteraciones, pero se hacía eco de las amenazas de un golpe de autoridad de la Alcaldía: "He concedido a los huertanos y demás vendedoras de los mercados de la ciudad un plazo de 48 horas para que ocupen los puestos. Pasado ese plazo, si no reanudan su vida ordinaria, serán dados de baja" 50 . Incluso sugería qué comportamientos vecinales podrían dejar fuera de juego al femater: "podía ser sustituido, invitando al vecindario a que, después de las diez de la noche sacara -no la arrojara como otras veces- a las puertas de sus casas, la basura, que recogería las brigadas de limpieza pública"51. No obstante, días más tarde, ambos periódicos informaban de un acuerdo en el que todas las reivindicaciones eran aceptadas, pero sólo para vendedoras y labradores del término municipal ${ }^{52}$. Este tipo de diferenciaciones entre vecinos y "foráneos" en las contraofertas de la corporación ya habían sido introducidas en anteriores conflictos en la huerta. Es posible que, ahora, con una deuda municipal galopante y las huelgas obreras, los concejales republicanos creyesen que así podrían calmar temporalmente las movilizaciones y ganar tiempo. Otra hipótesis alternativa sería que dicha selectividad respondiese a tácticas para dividir el movimiento huelguístico. En 1903, la aceptación de las condiciones municipales por parte de la SAV, arraigada en València, había contribuido a debilitar y desplazar el foco del conflicto hacia los pueblos aledaños ${ }^{53}$.

De cualquier manera, el final de la huelga en 1919 fue un cierre en falso. En octubre de 1920, y con un Ayuntamiento republicano empantanado en la cuestión de las subsistencias, arreciaron las protestas antifiscales de los fematers y las verduleras. Esta vez, la aprobación de un arbitrio de rodaje había soliviantado a los transportistas y, además, algunos fielatos habían intentado aplicarlo sobre los carros agrícolas. El alcalde Ricardo Samper aseguraba que todo se reducía a un malentendido:

Expuso que había manifestado a los huertanos que las hortalizas no devengaban el arbitrio y que si había exigido a algunos era debido a un error, y que había dado órdenes para que fuese subsanado. Pero que estos que habían mostrado siempre su ingratitud

48. Una anegada equivale a 1/12 hectárea. "La huelga de huertanos” El Pueblo: diario republicano, 15-11919.

49. Ibídem.

50. “Sigue la huelga de huertanos” Las Provincias, 16-1-1919.

51. Ibídem.

52. “Sesión municipal. La huelga de huertanos, solucionada” Las Provincias, 21-1-1919.

53. Las movilizaciones agrourbanas de 1901-1903 son analizadas en mi tesis doctoral, contrastándolas con el concepto de ciudad que estaba gestando el primer blasquismo. 
para con el Ayuntamiento no atendían estos cariñosos requerimientos para que cesaran en su actitud ${ }^{54}$.

Retrataba a los labradores como seres irracionales y correosos, condiciones agravadas porque ahora contaban con apoyo externo al campo. En última instancia, veía que su capacidad de acción podía diezmarse mediante coacciones legales. Si no claudicaban,

no tendría más remedio que recordar que únicamente existen unos 230 huertanos que tenían puestos en los mercados que son vecinos de Valencia, y que los demás que residen en distintos pueblos gozan de los beneficios de los huertanos de Valencia y extraen gracias a la benignidad del Ayuntamiento el estiércol de las casas particulares, por lo que muy bien podría llegarse a la implantación de un arbitrio por este concepto, o recoger la basura la Corporación por su cuenta ${ }^{55}$.

La duración del conflicto provocaría medidas inéditas. Cuatro días después, una moción encabezada por Samper y con la oposición de cuatro concejales conservadores y católicos apostaba por suprimir a perpetuidad las licencias para estercolar, quitar a las familias las concesiones de las paradas a las vendedoras y estudiar un sistema alternativo de recogida de basuras ${ }^{56}$. Mientras que los transportistas llegaron a un acuerdo, el gobernador civil ordenó, según El Pueblo, la disolución de la SAV y la captura de su junta rectora. Incluso las amenazas de Samper se cumplieron, desestimando las súplicas de los regidores conservadores, y de los alcaldes de Meliana, Alboraia, Almàssera y algunos comisionados de la Vega para revertir la situación ${ }^{57}$.

Para entender este recrudecimiento, probablemente sea necesario analizar otros factores que, junto a la conflictividad social y la identificación con el municipio, expliquen los debates en torno a la pertinencia del oficio del femater. En un cruce de cartas en 1917 en La Correspondencia de Valencia entre "un valenciano" y un supuesto labrador, su movilidad era expuesta como un vector de enfermedades entre el campo y la ciudad ${ }^{58}$. En una urbe que pronto padecería la gripe de 1918, la recepción de los discursos higienistas y médicos no debería ser soslayada para entender la dispar valoración social de sus labores de reaprovechamiento. En la Topografía Médica de Meliana, el doctor de esta población la calificaba sin tapujos de "estercolero de Valencia”, considerando una amenaza el contacto con el estiércol:

\begin{abstract}
diariamente ingresan en ella unos 200 carros de estiércol, con el que se benefician los campos. Pero si tal hecho es halagüeño para el agricultor, que ve aumentar satisfactoriamente sus cosechas, es altamente perjudicial para la salud pública, que se encuentra amenazada de continuo por el inminente contagio y propagación de las enfermedades infecciosas, cuyos gérmenes son transportados en el estiércol, que en grandes montones suele almacenarse en los corrales de las casas ${ }^{59}$.
\end{abstract}

La cuestión higiénica se había colado en la brecha identitaria entre el campo y ciudad levantada por los medios y la política municipal en los conflictos anteriores. En 1921, el cruce de acusaciones entre simpatizantes de los huertanos y detractores de su

54. AHMV, actas del pleno consistorial, 8-10-1920.

55. Ibídem.

56. AHMV, actas del pleno consistorial, 12-10-1920.

57. AHMV, actas del pleno consistorial, 12, 19 y 26-11-1920.

58. “Ecos de la opinión” La Correspondencia de Valencia, 25 y 26-9-1917.

59. Este trabajo fue premiado por el Instituto Médico Valenciano. José DuRÁn MARTínEZ, La Topografía Médica de Meliana, Valencia, Imprenta de la Revista Valenciana de Ciencias Médicas, 1915, p. 114. 
presencia en la ciudad dividía incluso a las filas republicanas. Francisco Puig Espert, vinculado a la rama regionalista del blasquismo, hablaba de "divorcio entre la ciudad y el campo" en una columna contra Samper y los prejuicios sobre los huertanos:

\begin{abstract}
A nuestros labradores no se les quiere en las calles ciudadanas, porque huelen a estiércol y van descalzos y en cuerpo de camisa; la castellanizada ciudad los expulsa de sus vías públicas, tal vez porque aún no les han corroído el pecho los aires de la meseta [...]. No volváis a la ciudad, buenas y sencillas gentes; no toméis a esa ciudad que solo se acuerda de vosotros para vestir, como decís muy bien, las cabalgatas y mostraros ridículamente al forastero en la feria de Julio, sobre el tablado de los bailes populares [...].

¡Que los concejales se las entiendan con la basura! ¿Podrán los cincuenta tribunos con todos los detritus de una población de 300.000 almas? ¡Cómo se ensuciarán las manos! ${ }^{60}$
\end{abstract}

El consistorio municipal había decidido zanjar la cuestión de manera definitiva. Según declaraciones del alcalde, el femater era una invasión y un peligro extintos. Sin contemplaciones: un "ejército de la muerte":

La pequeña molestia ahora se ocasiona al vecindario de bajar la basura a la calle es una garantía de higiene, porque ha acabado con la terrible invasión del femater en los hogares, yendo de la casa del varioloso a la del sano, de la del sífido a la del tuberculoso, y llevando a todas partes gérmenes patógenos.

El pasado año el Ayuntamiento expidió 1.138 licencias para estercolar. Ese terrible ejército de 1.138 fematers era, sin ellos quererlo, el ejército de la muerte que invadía los hogares y con el que ha acabado el Ayuntamiento ${ }^{61}$.

Con su ilegalización y la desaparición de las polémicas en la prensa, esta actividad parecía desvanecerse en pro de un servicio de limpieza municipal independiente del ecosistema agrario. O, al menos, ése era uno de los logros que políticos como Vicente Marco Miranda vindicaban en la postguerra de su legado como concejales blasquistas antes de la dictadura de Primo de Rivera ${ }^{62}$. Ahora bien, este silencio no acalla interrogarse sobre qué había ocurrido con las organizaciones antaño defensoras del femater. La SAV no había desaparecido, pero ¿quiénes estaban ahora detrás de ella? ¿Qué sentido tenía que reivindicase, junto a asociaciones comerciales, sindicatos y patronales católicas, una Mancomunitat Valenciana en los inicios de la dictadura? ${ }^{63}$ ¿O que en 1931 presentase candidatura en las elecciones municipales en el distrito de Ruzafa? Por el momento, quedan en el aire estos interrogantes.

\title{
Femejar en los albores del desarrollismo: historias orales (1950-1960)
}

No obstante, las historias y andanzas de este sujeto no terminan aquí. Hasta 2019, había quedado fuera de mi alcance la evolución de estas movilizaciones colectivas más allá de los confines temporales del primer blasquismo. Dadas las limitaciones del paper original (y el estado en que fue ideado, redactando la tesis doctoral) tampoco podía enfrascarme en un minucioso trabajo de recolección e

60. Francisco Puig EsPERT, “El campo y la ciudad”, Las Provincias, 8-6-1921.

61. “El discurso del Alcalde de Valencia en el Ateneo Mercantil” El Pueblo: diario republicano, 27-111921.

62. Vicente MARco MiRAndA, Memorias de Vicente Marco Miranda. In illo tempore, Valencia, Consell Valencià de Cultura, 2005, p. 360.

63. Ana María CerverA, "Derecha dinástica y modernización política”, en Aurora Bosch et alii, Estudios sobre la Segunda República, Valencia, Alfons el Magnànim, 1993, p. 35. 
interpretación de fuentes. Probablemente, esta fue la razón por la que retomé mi contacto inicial con esta profesión y modo de vida. Mi interés por los fematers partía de las conversaciones con mi abuelo y mi abuela maternos sobre sus historias de vida en un período más reciente, en los albores del desarrollismo franquista. Desde diferentes situaciones $^{64}$ y en un momento muy vívido para ambos (en la época de su boda) me explicaron cómo habían decidido complementar el cultivo y venta agrícola con la recogida de los residuos urbanos. Con ello, opté por entrevistarles, a expensas de sus posibles contactos con otras personas que habían desempeñado este oficio.

Hasta ahora, solo puedo conjeturar algunas hipótesis sobre el nuevo interés por reaprovechar los desperdicios urbanos. En el contexto de postguerra y autarquía, la limitación de las importaciones portuarias de fertilizantes químicos ha sido apuntada desde distintas perspectivas como un factor importante en el descenso de rendimientos de la tierra ${ }^{65}$. Al mismo tiempo, estas restricciones comerciales a priori situaban la alimentación procedente de los entornos periurbanos agropecuarios en una posición ventajosa por su cercanía e imbricación en los mercados, dadas las graves insuficiencias de las políticas municipales de abastecimiento y racionamiento en València y otras ciudades agrarias entre 1939 y 1951, todo ello sin contar el alivio vital que, con riesgos, podía suponer para vendedoras y pequeños labradores nutrirse e intercambiar sus cosechas por medio del "pequeño estraperlo" ${ }^{66}$. Esto permitiría que la materia orgánica e inorgánica producida en los hogares resultara apetecible como abono y fuente extra de ingresos para las familias labradoras que dispusiesen de un carro y una red de contactos.

De cualquier modo, a la luz de los cambios alentados por el consistorio franquista en la limpieza pública durante los años 1950, parece que la actividad de los fematers cobraba renovada legitimidad a través de la SAV superviviente de la posguerra. La abundante cantidad de multas registradas ${ }^{67}$ a la Compañía Valenciana de Mejoras Urbanas, empresa arrendataria del servicio, además de la finalización de su contrato, podría haber motivado el inicio de un proceso de licitación en 1955. Tras casi dos años de propuestas rechazadas, las disquisiciones municipales conllevarían un resultado doble. De la limpieza callejera se encargaría Fomento de Obras y Construcciones (actual FCC), mientras que la recogida domiciliaria de residuos sería gestionada por la $\mathrm{SAV}^{68}$, cuyo enlace con el mundo agrícola en esos momentos ofrece aún interrogantes.

Todas las personas entrevistadas insistieron en la estrecha relación entre la cría de puercos, patos o gallinas en las alquerías y el manejo de los desperdicios urbanos en

64. Pese a que mi abuela plantaba, cosechaba y vendía verdura en los mercados urbanos, el oficio del femater respondía a una división sexual del trabajo que probablemente estuviera reforzada por los estereotipos culturales de lo que resultaba decoroso para un hombre o una mujer en el primer franquismo. Sin embargo, una vez llegaban los desperdicios al corral, ella se encargaba también de su almacenamiento y selección.

65. Ricard Camil TORRes FABRA, Autarquia i estraperlo: l'economia en un espai rural del País Valencià durant el franquisme, Valencia, PUV, 2005, pp. 11-27.

66. Claudio Hernández Burgos y Francisco J. LEIRA CASTIÑEIRA, "Los rostros del hambre: autarquía, experiencias de miseria y estrategias de supervivencia durante la posguerra franquista (1939-1951)”, Historia Social, 97 (2020) pp. 84-89.

67. Solo en 1952, contabilizando los datos provenientes de las actas municipales, la corporación multó en 161 ocasiones a la CVMU por ineficiencia en la limpieza diaria (44,1\% del total anual).

68. AHMV, actas del pleno consistorial del 28-2 y 29-3-1957.

Rubrica Contemporanea, vol. X, n. 19, 2021. 
los años 1950. Así pues, dichos animales habían sido, al igual que la materia orgánica e inorgánica restante, fuente de ingresos y alimento en un contexto de aislamiento económico y carestía intermitente. Manuel Belloch reconocía haber contravenido con 14 años la edad mínima para llevar el carro y ayudar a su tío en la recogida de basura ${ }^{69}$. Esta precariedad podría explicar la insistencia, en un contexto de tímida liberalización económica en València tras el racionamiento ${ }^{70}$, de Miguel Catalá (posterior comerciante agrícola) o mis abuelos en las posibilidades de enriquecimiento y ascenso social que ofrecía su antiguo trabajo:

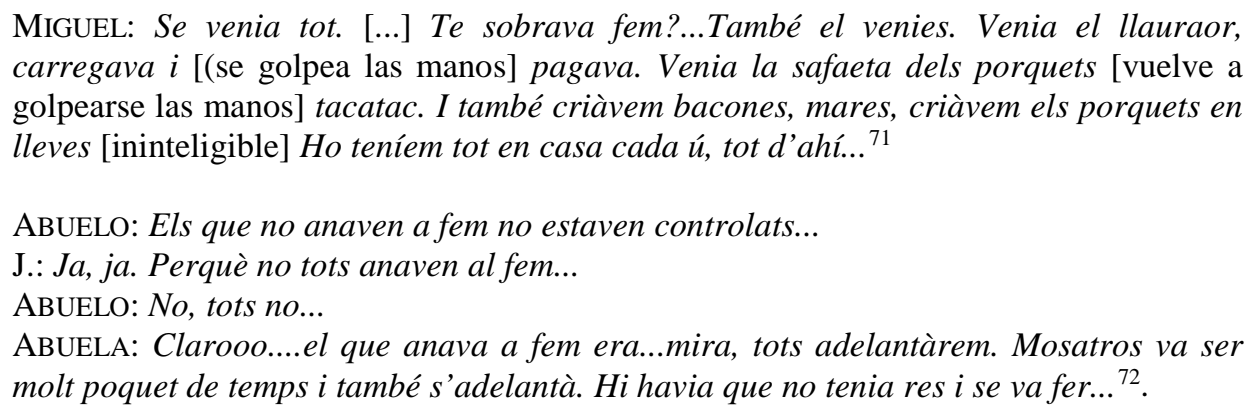

ABUELO: Els que no anaven a fem no estaven controlats...

J.: Ja, ja. Perquè no tots anaven al fem...

ABUELO: No, tots no...

ABUElA: Clarooo....el que anava a fem era...mira, tots adelantàrem. Mosatros va ser molt poquet de temps i també s'adelantà. Hi havia que no tenia res i se va fer... ${ }^{72}$.

Es posible que esta imagen de progreso esté condicionada a la memoria, no siempre fácil de identificarse con ella en el presente, que había dejado previamente los años del hambre y las penurias del racionamiento y el estraperlo ${ }^{73}$. Ahora bien, también hay que entender que no todas las familias podían dedicarse a la crianza de animales más allá de la autosubsistencia. En primer lugar, necesitaban un carro y un caballo para desplazarse. La importancia socioeconómica de este animal era aún mayor ya que, además de constituir un medio de transporte, les permitió trabajar la tierra hasta la compra de las primeras mulas mecánicas durante los años 1970, y en segundo lugar, requerían una continuidad temporal que ofreciera estabilidad laboral. De hecho, mis abuelos empezaron la cría solo cuando obtuvieron una volta de fem durante todo el año:

\footnotetext{
J.: Per què començares a anar al fem a València?

ABUElO: Per què comencí? Pues perquè no teníem un any complet per a anar a criar porcs. Eh? Hi hagué un home de la família que se va jubilar, bueno, que ja era major $i$ se volia jubilar...

J.: Sí...

ABUELO:...i tenia una volta de fem asignà a ell [silencio] contínua.

J.: Sí.

ABUELO:...i li ho diu a mon pare. I a mon pare li paregué bé. I agarràrem nosatros ixa volta de fem, perquè nosatros només que teníem quatre mesos en l'any, i en quatre mesos no podies criar animals, perquè estaven separats, no estaven junts...
}

69. Entrevista a Manuel Belloch Ferrer (17-10-2020).

70. Pese a que a partir de 1955 el porcentaje de población activa agrícola empezaría a bajar (del 48,5\% al $16,8 \%$ en 1975), el peso de este sector era todavía muy importante, hasta el punto de que las exportaciones agrícolas valencianas rondaban el 40\% del total estatal (Ismael SAZ, "Valencia en la etapa franquista: política y sociedad", en Paul PRESTON e Ismael SAZ (eds.), De la Revolución Liberal a la Democracia Parlamentaria. Valencia (1808-1975), Madrid, Biblioteca Nueva, 2001, pp. 272-273.

71. Entrevista a Miguel Catalá Omedes (15-6-2019).

72. Entrevista a Juan Ros Ten y Consuelo Hueso Pechuan (9-2-2019).

73. Gloria Román RuIZ, “'El pan negro de cada día’ memoria de 'los años del hambre’ en el mundo rural”, en Miguel Ángel Del ARCo BlAnCo (ed.), Los «años del hambre» Historia y memoria de la posguerra franquista, Madrid, Marcial Pons, 2020, pp. 345-366. 
La volta de fem consistía en un itinerario por varias calles de la ciudad, fijado de manera consuetudinaria por los propios fematers y sancionado por la $\mathrm{SAV}^{74}$, en el que ellos recogían con cubos durante las primeras horas de la mañana la basura generada por los vecindarios. Por un lado, la volta era el elemento que articulaba su interacción entre el mundo rural y urbano, así como su percepción de las desigualdades sociales que atravesaban en su recorrido:

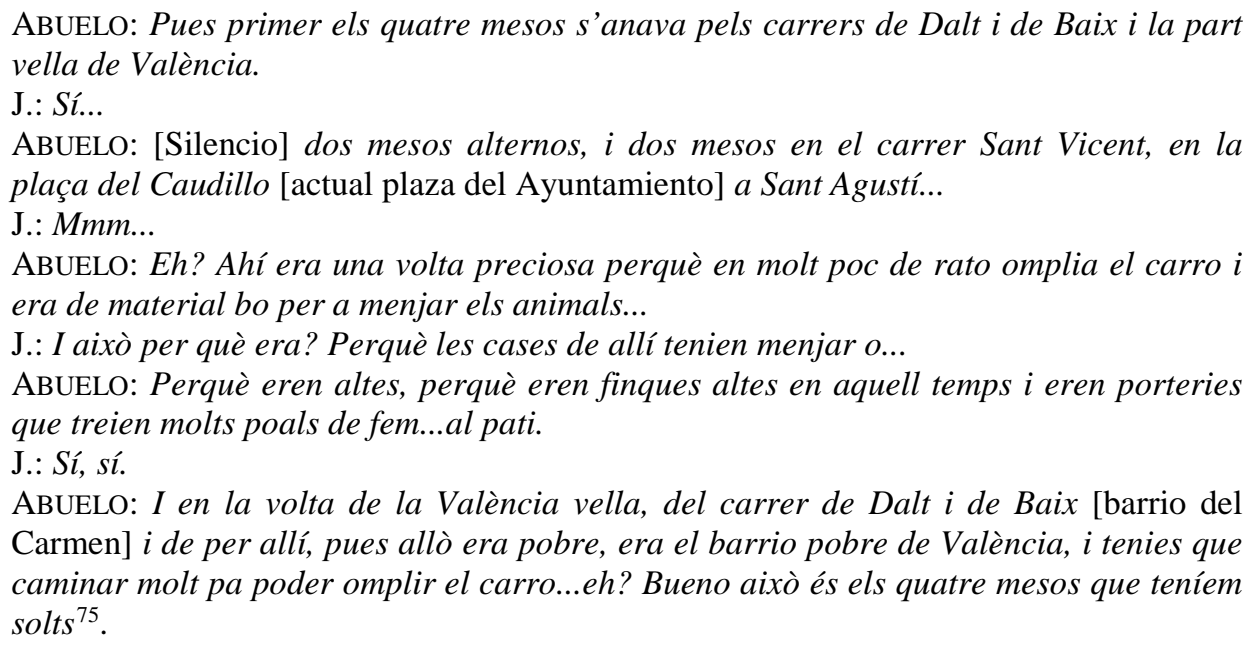

Por otro lado, las diferencias entre los recorridos asignados también derivaban en una creación de jerarquías internas dentro de los fematers, entre aquellos que gozaban de una volta productiva y los que no. Así pues, contar con un recorrido con alto nivel de desechos era comprendido como una posibilidad de bonanza:

ABUELO: I els [se lo piensa] més caciques del poble teníen les voltes més bones.

ENRIQUE: Home, claro...

ABUELO: Lo que eren finques altes de l'època, i acabaven molt prompte ${ }^{76}$.

En este sentido, resulta sugerente advertir la correlación, con tintes tayloristas, que mi abuelo establecía entre la altura de los bloques de edificios, la riqueza de sus residentes, la cantidad/calidad de los desperdicios generados y el tiempo que empleaba en su captación. Así pues, el recuerdo de la València pobre a finales de los años 1950 era asociada a su cansancio y esfuerzo adicional, en oposición a las fincas de la plaza del Ayuntamiento y la calle de San Vicente Mártir, zonas de gran actividad comercial y despliegue de proyectos urbanísticos desde finales del siglo XIX. Esta volta también podía englobar los residuos de cuarteles y fábricas del casco en los años 1950, tal y como rememora Manuel Belloch.

74. Dada la no conservación de sus archivos internos, desconozco qué cambios y continuidades internas existen entre la SAV de principios de siglo y la del franquismo.

75. Entrevista a Juan Ros Ten y Consuelo Hueso Pechuan.

76. Entrevista a Enrique Panach López (2-3-2019). 
Figura 2: Fotografía de Manuel Belloch con el carro de la basura de finales de los años 1950, cedida por su hija.

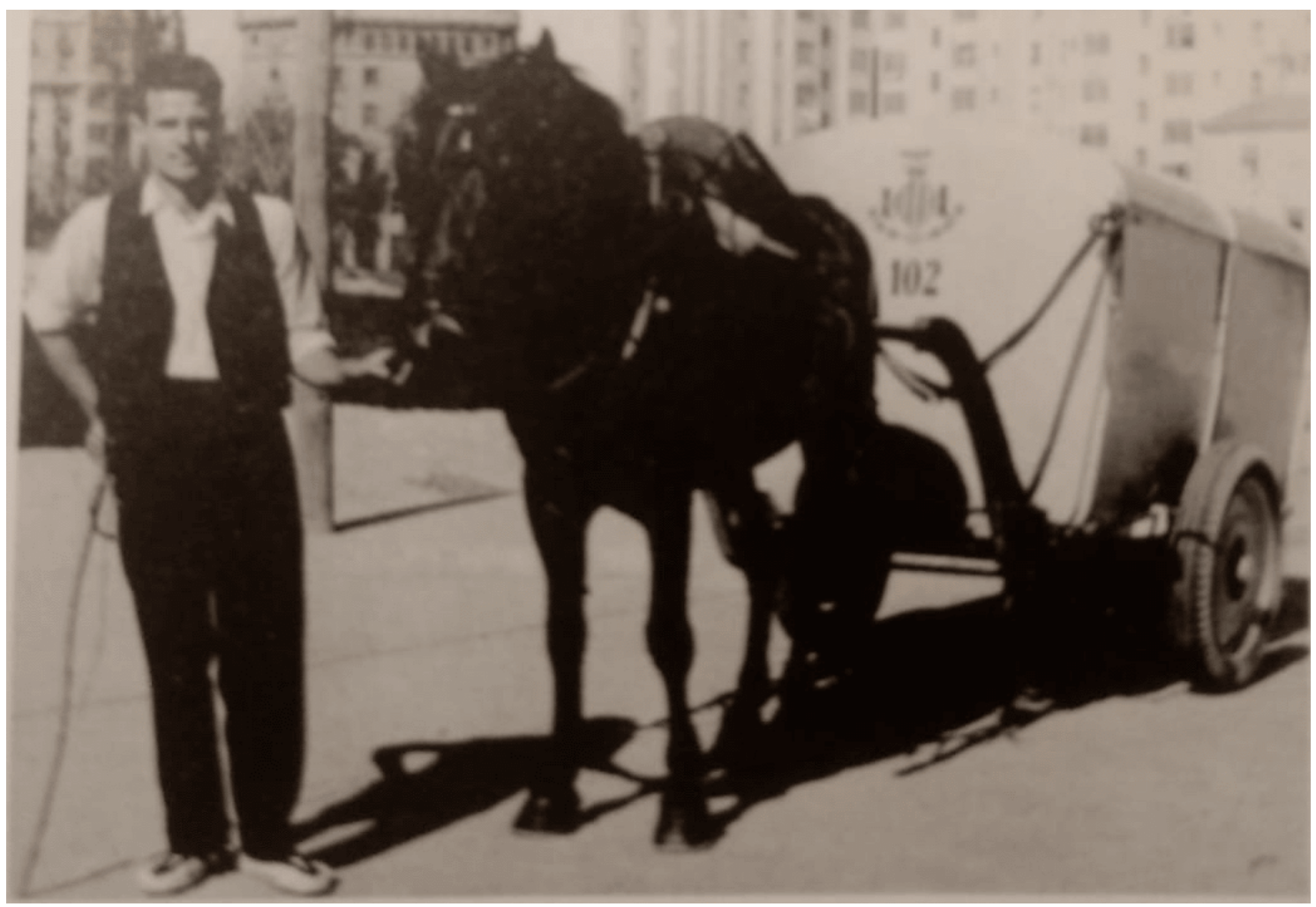

Por su escudo municipal, puede apreciarse que el Ayuntamiento proporcionaba los depósitos a los fematers, mientras ellos se encargaban de enganchar su caballo.

En un principio, Miguel, Enrique y mis abuelos coinciden en rememorar de manera nostálgica aquella etapa de sus vidas como una época de trabajo duro que les permitió comprar tierras y superar los últimos coletazos de la posguerra. En este proceso, parecían tejer una especie de memoria colectiva ${ }^{77}$ con la que se defienden ante un presente percibido como convulso e incomprensible. Por ejemplo, en sus relatos nada evoca un atisbo de conflictividad con las autoridades municipales o la SAV, sino más bien de deferencia. Se la representaba como un órgano de gestión y supervisión del trabajo de los fematers en la ciudad, lejos de la lucha callejera y la negociación política de principios del siglo XX:

ENRIQUE: Tenien uns inspectors també de particular, com mosatros, que miraven...tu no els veies...Si tenien confiança i sabien que eres bo i te saludaven, passaven per allí, però sempre pegaven una volta per a vore com ho fèiem, si arreplegàvem, si caia algo en terra...

J.: Sí, sí...

ENRIQUE: Claro, lo que passa, que estiguera curiós.

La búsqueda de mejores recorridos podía llevar a la creación, si era menester, de relaciones clientelares:

77. La familiaridad con la que las personas entrevistadas se apoyaban mutuamente en su relato me evocó el hogar del pasado de David LOWENTHAL: "Y es que el pasado, por lo general, no sorprende; se ha tomado su medida. En él estamos como en casa porque es nuestra casa; el pasado es el sitio del que procedemos” (El pasado es un país extraño, Madrid, Akal, 1998, p. 28). 
ENRIQUE: A vegades te la canviaven a una altra més roin, més bona [la volta]. Donaves... per què jo me'n recorde [se regodea] el abuelo que portava pollastres al tio Martínez [inspector de la SAV].

ABUELO: Exaacte. Al senyor Martínez.

ENRIQUE: Eh? En Nadal, algunes coses d'ixes, un remitjó de quereguilles... lo que havia, portaven a aquells... [intento preguntar y se adelanta] home, pa que te deixaren un poquet entrar en finques millors, que no era...

ABUELO: En, en... en carrers més bons, perquè o sinos els primers anaven tots a lo roin de València... ${ }^{78}$.

En el caso de Manuel, de los lazos entablados en el día a día surgían complicidades recordadas vívidamente por el propio entrevistado. Por ejemplo, a este antiguo femater le halagaba que José Durá, un propietario acomodado de una fábrica de naipes, se mostrase dispuesto a almorzar en el bar con él y su tío al término de su volta. Si bien, según él, la desigualdad social y el estatus presupuesto no eran óbice para tejer amistades, sí que provocaban situaciones con choques sensoriales que le parecían divertidos:

\begin{abstract}
ve un dia un, un representant, i va a la fàbrica, i claro... a vendre-li [imita al recepcionista]. No, està en el bar, armoçant. On? Allà. I entra, i clar, arriba i mosatros allí, qui anava a pensar ell que l'atre era el... no el coneixia, era la primera vegà que anava, i diu, escolte, don José Durá? Yo, yo, yo soy. Se girà [se ríe] assente's, assente's ahí, que [refiriéndose a los fematers] estos no tenen ni polls ni puces, estos lo que passa és que armoçen molt bé [se ríe]. I el tio allí, i li vingué justet pa fer-se un cafè. Però en acabant, sempre que anava allí quan tornava a la fàbrica venia allí a Don José... ${ }^{79}$.
\end{abstract}

En este día a día reconstruido por los entrevistados, el conflicto o el disenso abierto no constaba como opción de mejora de condiciones. Su lugar era ocupado por el respeto consuetudinario entre iguales:

Miguel: Pues bé, havia lo que coneixies, lo que anaves... era... és molt diferent a ara [...]. I antes quan te dien una paraula... sis són sis. No com ara que ara...uah, pues no ha canviat açò. Ara te la peguen en un minut [...].

ABUELO: Ja ho crec...

Miguel: I la serietat s'ha acabat, res. Antes anaven, a son pare, a comprar una collita... eh, de paraula... tants diners. Era una escritura. La paraula era... Hui ?.. Te la peguen [se regodea]. Antes anàvem en serietat, se respectàvem, cada ú lo seu...cada ú tenia el seu sector... ${ }^{80}$.

En sus declaraciones quizás reside un ligero poso bucólico de una aparente "normalidad sin política"81, concepto trabajado por Ismael Saz para estudiar las relaciones laborales en la industria de la posguerra valenciana y que no ha sido contrastado en los entornos agrarios. ¿Guardan algún tipo de conexión los testimonios que armonizan un pasado híbrido entre lo rural y lo urbano con la colonización antropológica del campesinado por parte del franquismo sostenida por Jesús Izquierdo? ${ }^{82}$ De todos modos, tal posibilidad no debería originar relatos desconflictivizados o argumentos circulares sobre la concienciación política. Aquí cabría explorar las escalas cromáticas manejadas por investigadoras como Gloria

78. Entrevista a Enrique Panach.

79. Entrevista a Manuel Belloch.

80. Entrevista a Miguel Catalá.

81. Ismael SAZ, “Trabajadores corrientes. Obreros de fábrica en la Valencia de la posguerra”, en ídem y Alberto GómEz RoDA (eds.), El Franquismo en Valencia: formas de vida y actitudes sociales en la posguerra, Valencia, Episteme, 1999, pp. 208-209.

82. IZQUIERDO, “El ciudadano demediado...”, pp. 648-649. 
Román para entender la evolución de las actitudes sociales hacia el régimen franquista en un mismo sujeto y en diversas vertientes: condiciones laborales, control moral, represión, etc. ${ }^{83}$ Allá donde iba, los sentidos del femater no se limitaban estrictamente a un "cumplimiento de sus funciones". De esta manera, Manuel recordaba más de sesenta años después con amargura los grilletes atados y las condiciones de los presos en el cuartel que limpiaba: “això t'ho conte perquè això és aixina, i hui en dia em poden dir lo que vulguen" ${ }^{84}$. Estas apreciaciones, así como otras que no evocasen consentimiento respecto a la actuación de las autoridades ${ }^{85}$, requerirían una investigación que cotejase los recuerdos a través de fuentes hemerográficas o documentación judicial.

Más allá de los significados políticos, existen divergencias entre las personas entrevistadas a la hora de evaluar la pertinencia de los medios empleados para prosperar en los años 1950-1960 y hacer de la basura un elemento productivo. Mientras que Miguel exaltaba la riqueza generada, Enrique y mi abuela matizaban desde su presente las connotaciones higiénicas del trabajo de femater y la cría de animales, con una pátina moral en el caso de ella. En todo caso, justificaban su ocupación como una etapa transitoria que habían de superar, argumentando el desconocimiento de otros modos de vida:

J.: Què, què era lo que anaves a dir?

IAIA: Te diu ta iaia [sí] que allò no era una cosa que era digna. Perquè els que estaven mals, estaven mals. Els donaven de menjar a les persones. I els porcs menjaven allí en el fem, que en el fem anava de tot...

J.: Sí, sí, però claro, era aixina com anàveu...

IAIA: Era aixina com anava la cosa, però no era una cosa recta ${ }^{86}$.

ENRIQUE: Jo en mon pare he pujat a netejar conilleres, dalt als terrats... no sé, la mare de Déu, açò serà precís?

ABUELO: Pues sí senyor.

ENRIQUE: Claro, entonces no coneixíem altra cosa. No coneixíem altra cosa ${ }^{87}$.

\section{Conclusiones}

Esta aproximación a la figura, los recorridos memorísticos y ecuestres del femater en tres contextos distintos (la València finisecular, 1916-1921 y los años 50-60) quizás pueda ser útil para reflexionar sobre los límites y estereotipos que, con nuevas formas y discursos, manejamos al recrear académica y personalmente nuestro espacio vivido. Las movilizaciones en los espacios públicos de València de vendedoras y fematers entre finales del siglo XIX y principios del XX tensionaron la distinción idealizada por las autoridades municipales republicanas entre sujetos $\mathrm{y}$

83. Gloria RomÁn, Franquismo de carne y hueso: entre el consentimiento y las resistencias cotidianas (1939-1975) Valencia, PUV, 2020, pp. 43-57.

84. Entrevista a Manuel Belloch.

85. De hecho, cabría investigar si las políticas franquistas de desarrollo generaron en las familias arrendatarias valencianas fuentes de malestar equiparables a las producidas por las plantaciones forestales, desarrollo de embalses y prohibiciones de prácticas como el pastoreo o la recolección de madera en regiones como Galicia o Extremadura (Teresa María ORTEGA LóPEZ, "Campesinos y jornaleros bajo el franquismo. Represión, disentimiento y conflictividad en el campo español, 1939-1975” en ídem y Francisco COBo Romero, La España rural, siglos XIX y XX: aspectos políticos, sociales y culturales, Granada, Comares, 2011, pp. 307-311).

86. Entrevista a Juan Ros Ten y Consuelo Hueso Pechuan.

87. Entrevista a Enrique Panach.

Rubrica Contemporanea, vol. X, n. 19, 2021. 
comportamientos urbanos y rurales. Mediante la parálisis del abastecimiento alimentario y la recolección de residuos domicilios, eran capaces de alterar los flujos comerciales y la movilidad en las calles y plazas. Tras la Gran Guerra, en un contexto de inestabilidad comercial y vaivenes de precios con repercusiones desiguales sobre la cadena alimentaria, los intentos municipales por fiscalizar y regularizar las funciones de los sujetos huertanos en la ciudad se saldarían con un recrudecimiento de las protestas de las familias labradoras de l'Horta Nord, y en concreto de los fematers. Los planos simbólicos y materiales del conflicto se entrelazarían en la prensa a través de los tópicos del bloqueo de València y una alteridad con este entorno agrícola que era apuntalada por medio de discursos higiénicos y decisiones políticas. El Gobierno republicano optaría por negarles el acceso a los residuos que gestionaban como elemento productivo y herramienta de negociación política. Sin embargo, parece ser que un nuevo contexto económico y los problemas municipales con la contrata de limpieza legitimarían en los años 1950 esta labor, resignificada al servicio de las autoridades franquistas. Este control no impedía que, a día de hoy, sus protagonistas percibiesen su trabajo como una fuente de enriquecimiento familiar que, pese a su dureza, les permitió dejar atrás la postguerra.

Estas situaciones permiten entender, a través del caso de València, que a lo largo de la primera mitad del siglo XX lo rural y lo urbano no constituyeron per se dos caras de una moneda o dos mundos crecientemente incompatibles. Más bien, podían formar un metabolismo que muta por unas relaciones de poder desiguales y cambiantes en los sujetos que manejan sus flujos de energía y materia. En la presente emergencia climática y crisis comercial, la apuesta por las redes de proximidad, el reaprovechamiento agrícola de lo urbano y la interdependencia ambiental y económica de ecosistemas agrarios y ciudades puede ser algo más que un bucólico recuerdo en sepia. 